Urgensitas Manajemen Lembaga Dalam Meningkatkan...

\title{
URGENSITAS MANAJEMEN LEMBAGA DALAM MENINGKATKAN KEPERCAYAAN MASYARAKAT
}

\author{
Abd. Wahib \\ FTIK IAIN Jember \\ abdwahid@gmail.com
}

\begin{abstract}
This paper is about the urgency of institutional management in increasing public trust which consists of management functions and applications as well as increasing public trust. Apply management functions in increasing public trust. Madrasah heads, teachers, and employees can carry out their duties properly in increasing public trust which includes: accommodation, cooperation, and assimilation. Application of institutional management in increasing trust in the community is expected to the head of the Madrasa or school to not hesitate to motivate and provide direction in carrying out tasks to subordinates in achieving goals both quality and quantity can be achieved in accordance with shared expectations. To teachers and employees to always be creative and innovative so that the development and progress of the institution is in line with the needs of society and the times. Of course, the hope for students to always be diligent in learning and maintaining the good name of the institution, because the challenges in the future will be more severe, therefore, as the next generation of national fighters must prepare themselves to face life in the future.
\end{abstract}

Keywords: Institutional Management, Community Trust.

\begin{abstract}
Tulisan ini tentang urgensitas manajemen lembaga dalam meningkatkan kepercayaan masyarakat yang terdiri dari fungsi dan aplikasi manajemen maupun peningkatan kepercayaan masyarakat. Mengaplikasikan fungsi manajemen dalam meningkatkan kepercayaan masyarakat. kepala Madrasah, guru, dan karyawan dapat menjalankan tugasnya dengan baik dalam meningkatkan kepercayaan masyarakat yang meliputi: akomodasi, kerja sama, dan asimilasi. Aplikasi manajemen lembaga dalam meningkatkan kepercayaan kepada msyarakat diharapkan kepada kepala Madrasah atau sekolah untuk tidak segan-segan memotivasi dan memberikan arahan dalam menjalankan tugas kepada bawahan dalam mencapai tujuan baik kualitas mupun kuantitas dapat dicapai sesuai dengan harapan bersama. Kepada para guru dan karyawan agar selalu bersikap kreatif dan inovatif sehingga perkembangan dan kemajuan lembaga sejalan dengan kebutuhan masyarakat dan perkembangan zaman. Tentunya harapan kepada peserta didik untuk selalu rajin belajar dan menjaga nama baik lembaga, karena tantangan dimasa yang akan datang lebih berat, maka dari itu sebagai generasi penerus pejuang bangsa haruslah mempersiapkan diri untuk menghadapi kehidupan dimasa yang akan datang.
\end{abstract}

Keywords: Manajemen Lembaga, Kepercayaan masyarakat. 
Abd Wahib

\section{PENDAHULUAN}

Lembaga pendidikan Islam merupakan wadah dalam pembentukan watak,sikap dan tingkah laku yang sifatnya Islami dengan tujuan pokoknya adalah mempersiapkan peserta didik agar mampu menjadi khalifah Allah SWT. Yang Mulia yang berarti lebih bertaqwa dan beriman kepada Allah SWT.

Mayoritas penduduk Indonesia beragama Islam, bahkan ummat Islam di Indonesia merupakan yang terbesar di dunia. Dengan komposisi penduduk yang demikian harus disadari bahwa keberadaan pendidikan Islam tidak bisa diremehkan meskipun masih ada beberapa kelemahan dan kenyataan bahwa tidak setiap muslim di negeri ini belajar dilembaga pendidikan Islam. ${ }^{1}$.

Manajemen pendidikan Islam adalah suatu proses pengelolaan lembaga pendidikan Islam secara Islami dengan cara mensiasati sumber-sumber belajar dan hal-hal lain yang terkait untuk mencapai tujuan pendidikan Islam secara efektif dan efisien. Makna definitif ini selanjutnya memiliki implikasi-implikasi yang saling terkait dalam membentuk satu kesatuan sistem dalam manajemen lembaga pendidikan Islam yaitu:

1. Proses pengelolaan lembaga pendidikan Islam secara Islami. Aspek ini menghendaki adanya muatan-muatan nilai Islam dalam proses pengelolaan lembaga pendidikan Islam. Misalnya pendekatan pada penghargaan, maslahat, kualitas, kemajuan dan pemberdayaan.

2. Terhadap lembaga pendidikan Islam. Hal ini menunjukkan objek dari manajemen ini yang secara khusus diarahkan untuk menangani lembaga pendidikan Islam dengan segala keunikannya

3. Proses pengelolaan lembaga pendidikan Islam secara Islami menghendaki adanya sifat inklusif dan eksklusif. Frase secara Islami menunjukkan sikap inklusif, yang berarti kaidah-kaidah manajerial yang dirumuskan dapat dapakai dalam mengalola lambaga pendidikan Islam sedangkang frase lembaga paendidikan Islam menunjukkan keadaan eksklusif karena menjadi objek langsung yang akan dikaji.

\footnotetext{
${ }^{1}$ Qomar, Mujammil. (2007). Manajemen Pendidikan Islam, Malang: Erlangga, p.43
} 
4. Dengan cara mensiasati. Frase ini mengandung strategi yang menjadi salah satu pembeda antara administrsi dengan manajemen. Manajemen penuh siasat atau strategi yang diarahkan untuk mencapai suatu tujuan. ${ }^{2}$

Demikian pendidikan agama Islam merupakan sistem nilai-nilai yang standardnya telah ditinjuk oleh Allah SWT, sebagaimana firmannya:

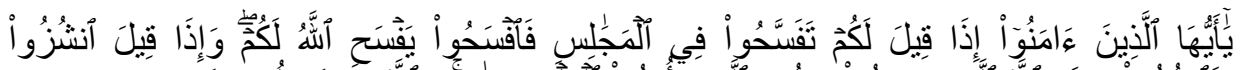

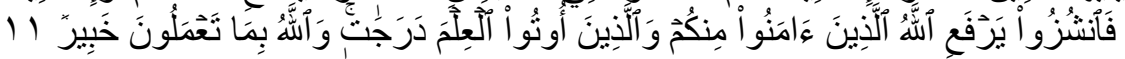

Artinya:

Hai orang-orang beriman apabila dikatakan kepadamu: "Berlapang-lapanglah dalam majlis", Maka lapangkanlah niscaya Allah akan memberi kelapangan untukmu. dan apabila dikatakan: "Berdirilah kamu", Maka berdirilah, niscaya Allah akan meninggikan orang-orang yang beriman di antaramu dan orang-orang yang diberi ilmu pengetahuan beberapa derajat. dan Allah Maha mengetahui apa yang kamu kerjakan (Qs. Al-Mujadalah:11). ${ }^{3}$

Masyarakat akan dihadapkan dalam suatu peradaban yang beragam bentuk dan kualitasnya, hal ini pasti terjadi karena sebagai akibat dari perkembangan ilmu pengetahuan dan teknologi, dan atau sebagai konsekwensi bergulirnya era globalisasi. Untuk menyikapi fenomena tersebut, keberadaan masyarakat akan dihadapkan pada sistem pendidikan yang multidimensi, sehingga masyarakat mampu menerima dan menyesuiakan terhadap arus perubahan yang terjadi pada lingkungannya.

Masyarakat modern telah berhasil mengembangkan ilmu pengetahuan dan teknologi canggih untuk mengatasi berbagai masalah kehidupannya, namun pada sisi lain ilmu pengetahuan dan teknologi canggih tersebut tidak mampu menumbuhkan moralitas (ahlak) yang mulia. ${ }^{4}$ Fenomena perkembangan zaman dari tahun ketahun selalu menghendaki adanya suatu sistem pembinan (kepribadian) yang komprehensif. Perkembangan masyarakat sampai dewasa ini menhendaki adanya lembaga pendidikan yang di dalamnya diselenggarakan suatu pembinaan secara optimal terhadap peserta didik

${ }^{2}$ Qomar, Mujammil. (2007). Manajemen Pendidikan Islam, Malang: Erlangga.p.11

${ }^{3}$ Departemen Agama Republik Indonesia, (1990). Al-Qur'an dan Terjamahnya, Surabaya: Mahkota.

${ }^{4}$ Nata, Abuddin. (2008). Manajemen Pendidikan Mengatasi kelemahan Pendidikan Islam Di Indonesia, Jakarta: Kencana Prenada Media Group.p.106 


\section{Abd Wahib}

secara seimbang antara nilai dan sikap, pengetahuan, keintelektualan dan keterampilan serta kemapuan komunikasi dan kesadaran akan ekologi lingkungan.

Dengan adanya azas pendidikan yang demikian itu mengabstraksikan suatu syarat untuk proses pembudayaan yang akan mempersiapkan seorang warga guna melakukan suatu pekerjaan yang menjadi pencahariannya dan berguna bagi masyarakatnya serta mampu beradaptasi diri secara konstruktif terhadap perubahan-perubahan yang terjadi secara signifikan. Dilain pihak, penemuan teknologi modern dan meningkatnya standart hidup manusia dapat mengakibatkan terhadap proses kehidupan sehari-hari, dengan adanya pengahsilan yang cukup banyak orang tua yang cenderung meningkatkan pemenuhan kebutuhan konsumtif didalam keluarga masing-masing mereka menjadi lengah tidak merasa perlu untuk mempersiapkan mental anak-anak dan minimnya nilai kesadaran akan tantangan hidup dalam menggulangi era globalisasi dan teknologi yang semakin menekan.

Bicara eksistensi lembaga pendidikan Islam, maka dalam menjalankan lembaga tidak akan terlepas dari mamajemen, dan manajemen tidak akan terlepas pemimpin (manajer), sebab manajemen dan manajer sangat berpengaruh terhadap kualitas sesuatu organisasi atau lembaga. Bagaimana seorang pemimpin dengan manajemennya mampu mengantisipasi perkembanga dan kebutuhan suatu lembaga yang dipimpin pada suatu masa yang akan datang.

Dalam kaitan dengan hal di atas nampaknya fungsi manajemen merupakan sebuah sarana atau alat untuk memajukan sebuah lembaga atau organisasi, termasuk lembaga pendidikan Islam (LPI) khususnya dengan kajian manajemen. Dengan demikian jelaslah bahwa manajemen merupakan salah satu faktor keberhasilan dari suatu lembaga, maka dari itulah optimalisasi fungsi manajemen disuatu lembaga sangat diperlukan walaupun tidak semua fungsi manajemen dapat diterapkan dalam sebuah lembaga pendidikan. Hal ini disadari karena manajemen itu sendiri muncul dan berkembang di dunia perusahaan dan industri. Maka untuk menerapkan manajemen kedalam dunia pendidikan diperlukan penyaringan yang betul-betul selektif, dengan demikian diharapkan terjadi keseimbangan 
dan kesesuaian hingga akhirnya menghasilkan output yang maksimal dan berdaya saing tinggi.

Pengaplikasian fungsi manajemen pendidikan mutlak diperlukan tak terkecuali dilembaga pendidikan, khusus kaitannya dengan kajian ini yang merupakan suatu lembaga atau intitusi pendidikan. Saat sekarang dalam studi awal atau observasi awal yang ada dilapangan menarik perhatian penulis untuk mengetahui bagaimana manajemen lembaga tersebut, hal ini dikarenakan beberapa tahun belakangan ini terjadi kemajuan yang signifikan.

Demikian pula halnya dengan mengelolaan staf yang professional dengan maksud agar sesuai dengan job description-nya (fungsi/keahliannya). Apabila hal ini tidak diperhatikan, maka akan terjadi overlapping (tumpang tindih tugas atau pekerjaan). Untuk mengatasi hal ini dibutuhkan seorang pemimpin yang dapat mengatur dan menjadi figur di dalam pengelolaan lembaga pendidikan yang di dalamnya terdapat pengawasan atau pengendalian untuk mengetahui sejauh mana efektifitas dan efisiensi dari program yang ada.

\section{PEMBAHASAN}

\section{Manajemen Lembaga Pendidikan Islam}

Istilah manajemen merupakan Istilah yang digunakan untuk menerjemahkan kata "management". Definisi manajemen yang sering dikemukakan adalah "management as the art of getting things done through people" artinya manajemen adalah seni menyelesaikan pekerjaan dengan melalui orang lain. Berdasarkan istilah manajemen itu maka orang yang melaksanakannya disebut manajer. Sejalan dengan perkembangan ilmu pengetahuan sacara umum, dan kajian ilmu manajemen secara khusus, definisi manajemen juga mengalami perkembangan dengan memberikan uraian yang lebih spesifik melalui penyebutan fungsi-fungsi yang harus dilaksanakan oleh seorang manajer dalam menjalankan tugasnya. ${ }^{5}$

\footnotetext{
${ }^{5}$ Mujahid, Dkk. (2003). Manajemen Madrasah Mandiri, Jakarta: Puslitbang Pendidikan agama Dan keagamaan.p.1
} 
Abd Wahib

Manajemen adalah sebuah proses yang khas terdiri dari perencanaan, pengorganisasian, penggerakan, dan pengawasan yang dilakukan untuk mencapai tujuan organisasi dengan memberdayakan sumber daya manusia dan sumber daya lainnya. ${ }^{6}$ Manajemen pendidikan Islam adalah suatu proses pengelolaan lembaga pendidikan Islam secara Islami dengan cara mensiasati sumber-sumber belajar dan hal-hal lain yang terkait untuk mencapai tujuan pendidikan Islam secara efektif dan efisien.

Makna definitif ini selanjutnya memiliki implikasi-implikasi yang saling terkait dalam membentuk satu kesatuan sistem dalam manajemen lembaga pendidikan Islam yaitu:

1) Proses pengelolaan lembaga pendidikan Islam secara Islami. Aspek ini menghendaki adanya muatan-muatan nilai Islam dalam proses pengelolaan lembaga pendidikan Islam. Misalnya penekatan pada penghargaan, maslahat, kualitas, kemajuan dan pemberdayaan.

2) Terhadap lembaga pendidikan Islam. Hal ini menunjukkan objek dari manajemen ini yang secara khusus diarahkan untuk menangani lembaga pendidikan Islam dengan segala keunikannya.

3) Proses pengelolaan lembaga pendidikan Islam secara Islami menghendaki adanya sifat inklusif dan eksklusif. Frase secara Islami menunjukkan sikap inklusif, yang berarti kaidah-kaidah manajerial yang dirumuskan dapat dapakai dalam mengalola lambaga pendidikan Islam sedangkang frase lembaga paendidikan Islam menunjukkan keadaan eksklusif karena menjadi objek langsung yang akan dikaji.

4) Dengan cara mensiasati. Frase ini mengandung strategi yang menjadi salah satu pembeda antara administrsi dengan manajemen. Manajemen penuh siasat atau strategi yang diarahkan untuk mencaoai suatu tujuan. ${ }^{7}$

\footnotetext{
${ }^{6}$ Mulyono. (2008). Manajemen Administrasi \& Organisasi Pendidikan, Jogjakarta: Ar-Ruzz Media.p.35

${ }^{7}$ Qomar, Mujammil. (2007). Manajemen Pendidikan Islam, Malang: Erlangga, P.11
} 
Diketahui bahwa fungsi manajemen itu banyak sekali dan berbeda-beda tergantung dari sudut pandang mana para ahli menilainya. Di dalam penelitian ini hanya akan membahas empat fungsi manajemen yaitu: perencanaan, pengorganisasian, pengarahan, dan pengawasan. Keempat fungsi manajemen tersebut disesuaikan dengan bidang keilmuan yang peneliti tekuni selama ini yaitu pengelolaan lembaga pendidikan Islam, maka dari itu keempat fungsi manajemen yang peneliti ambil dalam penelitian akan difokuskan pada lembaga.

\section{Manajemen Lembaga Dalam Meningkatkan Kepercayaan masyarakat}

Sekolah sebagai lembaga pendidikan sudah semestinya mempunyai organisasi yang baik agar tujuan pendidikan formal dapat tercapai dengan semastinya. Kita mengetahui bahwa unsur personal di dalam lingkungan sekolah adalah, kepala madrasah, Guru, Karyawan dan murid. Disamping itu sekolah sebagai lembaga pendidikan formal ada di bawah intansi atasan baik itu kantor dinas atau wilayah departemen yang bersangkutan. ${ }^{8}$

Dalam undang-undang republik Indonesia nomor 20 tahun 2003 tentang sistem pendidikan nasional bab I pasal 1 ayat 10-11 menyatakan bahwa satuan pendidikan adalah kelompok layanan pendidikan yang menyelenggarakan pendidikan pada jalur formal, non formal, dan informal pada setiap jenjang dan jenis pendidikan. Sedangkan pendidikan formal adalah jalur pendidikan yang berstruktur dan berjenjang yang terdiri atas pendidikan dasar, pendidikan menengah, dan pendidikan tinggi. ${ }^{9}$

Fungsi manajemen lembaga dalam meningkatkan kepercayaan masyarakat adalah rangkaian kegiatan atau keseluruhan proses pengendalian usaha kerja sama sejumlah orang uantuk mencapai tujuan pendidikan secara berencana dan sistimatis yang diselenggarakan dalam lingkungan tertentu, terutama dalam lembaga pendidikan formal guna memperoleh dukungan dan partisipasi masyarakat.

Menurut Mudjahid dalam bukunya yang berjudul "Manajemen Madrasah Mandiri" menyatakan bahwa terdapat tiga fungsi manajemen dengan istilah yang sama yaitu: fungsi

\footnotetext{
${ }^{8}$ Suryosubrato. (2004). Manajemen Pendidikan Di Sekolah, Jakarta: Reneka Cipta, p.138

${ }^{9}$ Sekretariat Negara R.I.,(2003), Undang-Undang Republik Indonesia Nomor 20 Tahun 2003 Tentang Sistem Pendidikan Nasional, Jakarta: Armas Duta Jaya.
} 


\section{Abd Wahib}

Perencanaan (planning), Fungsi pengorganisasian (organižing), dan fungsi pengawasan atau pengendalian (controlling). ${ }^{10}$

Adapun fungsi manajemen yang akan dibahas dalam penelitian ini adalah fungsi perencanaan, fungsi pengorganisasian, fungsi pengarahan dan fungsi pengawasan.

a. Perencanaan

Perencanaan merupakan suatu aktivitas atau kegiatan yang harus dilakukan dalam sitiap memulai suatu pekerjaan, tanpa perencanaan yang matang dalam suatu kegiatan akan mengalami kesulitan bahkan akan mengalami kegagalan dalam mencapai tujuan. Menurut Nanang Fattah dalam bukunya yang berjudul "Landasan Manajemen Pendidikan” menyatakan bahwa perencanaan adalah proses penentuan tujuan atau sasaran yang hendak dicapai dan menetapkan jalan dan sumber yang diperlukan untuk mencapai tujuan. ${ }^{11}$

Perencanaan merupakan aktivitas utama yang dilakukan oleh setiap manajer. Hal tersebut karena rencana yang dibuat akan menggambarkan sasaran organisasi dan prosedur yang terbaik untuk mencapai sasaran tersbut. Fungsi ini menimbulkan implikasi bahwa tahap pertama yang harus dilaksanakan dalam perencanaan adalah menyusun langkah-langkah untuk mencapai tujuan-tujuan organisasi. Fungsi perencanaan antara lain mencakup: Penetapan tujuan dan standar, penentuan aturan dan prosedur, pembuatan rencana dan peramalan apa yang akan terjadi dimasa yang akan dating. ${ }^{12}$

Allah berfirman dalan Al-Qur'an surah Al- Hasyr ayat18

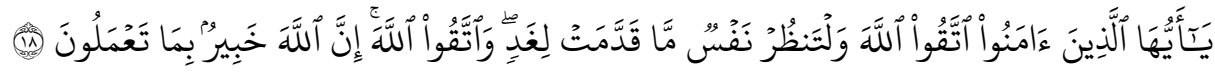

Artinya:

Hai orang-orang yang beriman bertakwalah kepada Allah dan hendaklah setiap diri memerhatikan apa yang telah diperbuatnya untuk hari esok (akhirat) dan

\footnotetext{
${ }^{10}$ Mujahid, Dkk. (2003). Manajemen Madrasah Mandiri, Jakarta: Puslitbang Pendidikan agama Dan keagamaan, p.4-5

${ }^{11}$ Fattah, Nanang. (2003). Landasan Manajemen, Bandung: PT. Remaja Rosdakarya.p.49

${ }^{12}$ Mujahid, Dkk. (2003). Manajemen Madrasah Mandiri, Jakarta: Puslitbang Pendidikan agama Dan keagamaan.p.5
} 
bertakwalah kepada Allah, saesungguhnya Allah maha mengetahui apa yang kamu kerjakan. ${ }^{13}$

Menurut Mujamil Qomar dalam bukunya yang berjudul "Manajemen Pendidikan Islam" ayat ini memberikan pesan kepada orang-orang yang beriman untuk memikirkan masa depan. Dalam bahasa Manajemen, pemikiran masa depan dituangkan dalam konsep yang jelas dan sistematis ini disebut perencanaan (planning). Perencanaanini menjadi sangat penting Karena berfungsi sebagai pengarah kegiatan, target-target, dan hasil-hasilnya dimasa depan hingga apapun kegiatan yang dilakukan dapat berjalan dengan tertib. ${ }^{14}$

b. Pengorganisasian

Pengorganisasian sebagai fungsi manajemen menjadi tugas utama bagi para pemimpin pendidikan termasuk kepala madrasah. Dalam kegiatan sehari-hari di sekolah terdapat bernacam-macam bentuk kegiatan yang tidak mungkin dilakukan sendiri dan memerlukan keahlian dan tanggung jawab yang berbedabeda. Oleh karena itu, seorang kepala Madrasah dituntut untuk mempunyai kecakapan dan keterampilan dalam mengorganisasikan karyawan dan para guru dalam menjalankan tugasnya sehingga terjalin hubungan yang akrab dan harmonis.

Di dalam berlangsungnya kegiatan sekolah maka unsur manusia merupakan unsur penting, karena kelancaran jalanya pelaksanaan program sekolah sangat ditentukan oleh manusia-manusia yang menjalankannya. ${ }^{15}$

Pengorganisasian merupakan proses pengaturan dan pengalokasian kerja, wewenang, dan sumber daya dikalangan anggota organisasi sehingga mereka dapat mencapai tujuan organisasi secara efisien. Pengalokasian tersebut secara sederhana dapat dilihat pada struktur organisasiyang digunakan. Pengorganisasian juga mengisyaratkan bahwa sasaran yang berbeda memerlukan struktur organisasi yang berbeda. Fungsi pengorganisasian antara lain meliputi: pemberian tugas-

\footnotetext{
${ }^{13}$ Departemen Agama Republik Indonesia, (1990). Al-Qur'an dan Terjamahnya, Surabaya: Mahkota.

${ }^{14}$ Qomar, Mujammil. (2007). Manajemen Pendidikan Islam, Malang: Erlangga.p.30

${ }^{15}$ Daryanto. (1998). Administrasi pendidikan, Jakarta, Reneka Cipta.p.29
} 
Abd Wahib

tugas yang terpisah kepada setiap bawahan, menetapkan jalur wewenang dan komunikasi, serata mengordinasikerja bawahan.

Ali Bin Abi Thalib mengatakan الحق بلا نظام يغلبه الباطل بالنظام yang artinya: "Kebenaran yang tidak terorganisasi dapat dikalahkan oleh kebatilan yang terorganisasi”.

c. Pengarahan

Pengarahan sebagai suatu usaha untuk menjaga agar apa yang telah direncanakan dapat berjalan susuai dengan yang diharapkan.

Fungsi pengarahan adalah fungsi yang berkenaan dengan pemberian stimulasi kepada anggota organisasi untuk mengambil tindakan yang sesuai dengan rencana. Fungsi pengarahan ini meliputi menciptakan suatu iklim dengan kombinasi yang baik dan situasi yang kondusif untuk memimpin dari motifasi orang-orang secara efektif. ${ }^{16}$

Pegawai yang telah dimiliki lembaga pendidikan Islam, baik yang berstatus pegawai negeri maupun swasta, harus diberi wahana untuk proses pembinaan dan pengembangan. Pembinaan lebih berorientasi pada pencapaian standar minimal yaitu diarahkan untuk dapat melakukan pekerjaan/tugasnya sebaik mungkin dan menghindari pelanggaran. ${ }^{17}$

d. Pengawasan

Melakukan suatu tugas hanya mungkin dealakukan dengan baik apabila seseorang yang melaksanakan tugas itu mengerti arti dan tujuan dari tugas yang dilaksanakan. Seorang pemimpin yang melakukan tugas pengawasan haruslah sungguh-sungguh mengerti arti dan tujuan dari pada pelaksanaan tugas pengawasan.

Menurut Hikmat pengawasan adalah suatu kegiatan manajer yang mengusahakan agar semua pekerjaan terlaksana sesuai dengan rencana yang ditetapkan dan mencapi hasil yang dikehendaki. Langkah-langkah pengawasan adalah:

\footnotetext{
${ }^{16}$ Mujahid, Dkk. (2003). Manajemen Madrasah Mandiri, Jakarta: Puslitbang Pendidikan agama dan keagamaan.p.6

${ }^{17}$ Qomar, Mujammil. (2007). Manajemen Pendidikan Islam, Malang: Erlangga.p.133
} 
1. Memeriksa semua pelaksanaan rencana

2. Mengecek semua detail aktivitas lembaga

3. Mencocokkan antara pelaksanaan dengan rencana yang sudah ditetapkan

4. Mengendalikan seluruh pengelolaan lembaga

5. Mengtur pelaksanaan sesuai dengan tugas dan fungsi pelaksanaan kegiatan

6. Mencegah sebelum terjadi kegagalan. ${ }^{18}$

Fungsi pengawasan atau pengendalian adalah fungsi yang harus dilaksanakan manajer untuk memastikan bahwa anggota melakukan aktivitas yang akan membawa organisasi kearah tukuan yang telah ditetapkan. Pelaksanaan fungsi ini akan melahirkan implikasi bahwa manajer perlu menentukan stadar kinerja organisasi, mengukur kinerja yang sedang berjalan, membandingkan kinerja dengan standar yang telah ditetapkan, dan mengambil tindakan apabila ditemui penyimpangan.

\section{Pelaksanaan Manajemen Lembaga Dalam Meningkatkan Kepercayaan Masyarakat}

Lembaga pendidikan merupakan alat untuk mencapai tujuan pendidikan. Dalam lembaga pendidikan terdapat kepala sekolah, para pendidik, karyawan, anak didik, fasilitas sarana dan prasarana pendidikan, dan sebagainya. Dengan gambaran tersebut setiap organisasi termasuk lembaga pendidikan membutuhkan proses manajerial yang koperhensif, karena kesuksesan suatu organisasi sangat ditentukan oleh kejelian dan integritas semua bidang atau sub bidang atau sebut saja komponen-komponen organisasi yang merupakan sumber daya manusia dan sumber daya yang mendukung terlaksananya semua rencana organisasi. ${ }^{19}$

a. Perencanaan

${ }_{19}^{18}$ Hikmat. (2009). Manajemen Pendidikan, Bandung: Pustaka Setia, p.123

19 Hikmat. (2009). Manajemen Pendidikan, Bandung: Pustaka Setia.p.15 
Abd Wahib

Perencanaan adalah proses kegiatan rasional dan sistemik dalam menetapkan keputusan, kegiatan atau langkah-langkah yang akan dilaksanakan dikemudian hari dalam rangka mencapai tujuan secara efektif dan efisien. ${ }^{20}$

Menurut Hikmat dalam bukunya Manajemen Pendidikan Perencanaan pendidikan adalah Kegiatan yang berkaitan dengan usaha merumuskan program pendidikan, prosedur, dan metode yang akan diikuti dalam usaha mencapai tujuan pendidikan.

Sedangkan menurut Mudjahid perencanaan berarti menentukan lebih dahulu program ketenagaan yang akan membantu tercapainya tujuan Madrasah yang telah ditetapkan. ${ }^{21}$

Perencanaan merupakan salah satu syarat mutlak bagi setiap organisasi atau lembaga dan bagi setiap kegiatan, baik perorangan maupun kelompok. ${ }^{22}$

Dengan demikian perencanaan mengandung arti:

1. Manajer memikirkan dengan matang terlebih dahulu sasaran (tujuan) dan tindakan berdasarkan pada beberapa metode, rencana, atau logika dan bukan berdasarkan perasaan.

2. Rencana mengarahkan tujuan organisasi dan menetapkan prosedur terbaik untuk mencapainya.

3. Rencana merupakan pedoman untuk organisasi memperoleh dan menggunakan sumber daya yang diperlukan untuk mencapai tujuan serta untuk melaksanakan aktivitas yang konsisten dengan tujuan dan prosedur yang sedah ditetapkan.

Berdasarkan pendapat diatas perencanaan merupakan persiapan yang teratur dari setiap usaha untuk mencapai tujuan yang telah ditetapkan serta untuk

20 Mulyono. (2008). Manajemen Administrasi \& Organisasi Pendidikan, Jogjakarta: Ar-Ruzz Media.p. 25

21 Mujahid, Dkk. (2003). Manajemen Madrasah Mandiri, Jakarta: Puslitbang Pendidikan agama Dan keagamaan

22 Purwanto, Ngalim. (2009). Administrasi Dan Supervisi Pendidikan, Bandung: PT. Remaja Rosdakarya.p.106 
melihat kedepan dalam rangka memperkecil resiko yang mungkin muncul berupa kesalahan atau kemungkinan kegagalan.

b. Pengorganisasian

Pengorganisasian adalah munyusun hubungan prilaku yang efektif antar personalia, sehingga mereka dapat bekerja sama secara efisien dan memperoleh keputusan pribadi dalam melaksanakan tugas-tugas dalam situasi lingkungan yang ada guna mencapai tujuan dan sasaran tertentu. ${ }^{23}$ Pengorganisasian adalah proses menghubungkan orang-orang yang terlibat dalam organisasi pendidikan dan menyatupadukan tugas serta fungsinya dalam sistem jaringan kerja yang relationship antara satu dan yang lainnya. Dalam proses pengorganisasian suatu lembaga pendidikan, manajer menetapkan pembagian tugas, wewenang, dan tanggung jawab secara rinci berdasarkan bagian dan bidangnya masing-masing sehingga terintegrasi hubungan-hubungan kerja yang sinergis, koperatif, harmonis, dan seirama dalam mencapai tujuan yang telah disepakati bersama.

Adapun firman Allah SWT. Yang berkenaan dengan pengorganisasian adalah surat Al-imran ayat 104:

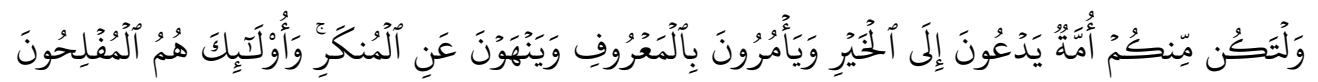

Artinya:

Dan hendaklah ada diantara kamu segolongan ummat yang menyeru kepada kebajikan, menyuruh kepada yang ma'ruf dan mencegah dari yang mungkar, mereka itulah orang-orang yang beruntung (Qs. Al-Imran: 104). ${ }^{24}$

Jadi sekolah sebagai suatu lembaga pendidikan yang di dalamnya terdapat kepala Madrasah, guru, pengawai tata usaha dan lain sebagainya, semuanya memerlukan pengorganisasian yang baik agar lembaga dalam meningkatkan mutu pendidikan dapat berjalan dengan baik sehingga berdampak positif dalam hal kepercayaan masyarakat.

${ }^{23}$ Mulyono. (2008). Manajemen Administrasi \& Organisasi Pendidikan, Jogjakarta: Ar-Ruzz Media.p.27

${ }^{24}$ Departemen Agama Republik Indonesia, (1990). Al-Qur'an dan Terjamahnya, Surabaya: Mahkota. 
Abd Wahib

c. Pembimbingan

Menurut Mujamil Qomar dalam bukunya manajemen pendidikan Ialam menyatakan pengawai yang telah dimiliki lembaga pendidikan Islam, baik yang berstatus pegawai negeri maupun swasta, harus diberi wahana untuk proses pembinaan dan pengembangan. Pembinaan lebih berorientasi pada pencapaian standar minimal, yaitu dirahkan untuk dapat melakukan pekerjaan/tugasnya sebaik mungkin dan menghindari pelanggaran. ${ }^{25}$

Dari pendapat diatas dapatlah diambil suatu bentuk bimbingan yaitu:

1. Memberi dan menjelaskan perintah

2. Memberikan petunjuk melaksanakan suatu kegiatan

3. Memberikan kesempatan untuk ikut serta menyumbangkan tenaga dan fikiran serta kreatifitas masing-masing.

d. Koordinasi

Dalam menjalankan aktivitas manajerialnya, seorang manajer memiliki dua macam sumber daya yaitu sumber daya manusia dan sumber daya non manusia (material). Kepemilikan ini menimbulkan implikasi bahwa seorang manajer harus mampu melakukan kombinasi dan koordinasi dalam memanfaatkan atau menggunakan sumber daya yang ada demi pencapaian organisasi. Upaya pemanfaatan atau penggunaan sumber daya tersebut harus memperhatikan aspek efisiensi dan aspek efektivitas.

Menurut Daryanto, pengkoordinasian adalah kegiatan menghubungkan orang-orang dan tugas-tugas sehingga terjalin kesatuan tau keselarasan keputusan, kebijaksanaan, tindakan, langkah, sikap serta tercegah dari timbulnya pertentangan, kekacauan, kekembaran (duplikasi), dan kekosongan tindakan. ${ }^{26}$

Program atau rencana lembaga pendidikan yang harus dilaksanakan sifatnya sangat kompleks dan banyak mengandung segi yang saling bersangkut paut satu sama lain. Sifat kompleks inilah yang mengharuskan adanya koordinasi

${ }^{25}$ Qomar, Mujammil. (2007). Manajemen Pendidikan Islam, Malang: Erlangga, p.133

${ }^{26}$ Daryanto. (1998). Administrasi pendidikan, Jakarta, Reneka Cipta, p.83 
satu sama lainnya agar dalam memecahkan masalah atau dalam menyelesaikan suatu pekerjaan tidak terjadi simpang siur sehingga dapat mencapai tujuan yang telah ditetapkan.

e. Evaluasi

Evaluasi adalah proses pengukuran dan pembandingan hasil- hasil yang telah dicapai secara nyata dengan hasil-hasil yang seharusnya dicapaisesuai dengan yang telah ditetapkan. Evaluasi erat hubungannya dengan penilaian yaitu memberikan nilai tau angka kualitatif terhadap hal yang dievaluasi sehingga tergambar tingkat perbandingan antara hasil yang dicapai dengan patokan yang telah ditetapkan. ${ }^{27}$

Mengevaluasi artinya menilai semua kegiatan untuk menemukan indicator yang menyebabkan sukses atau gagalnya pencapaian tujuan, sehingga dapat dijadikan bahan kajian berikutnya. ${ }^{28}$

Dalam Undang- Undang RI No.20 Tahun 2003 tentang sistem pendidikan nasional bab1 ayat 21 menyatakan evaluasi pendidikan adalah kegiatan pengendalian, penjaminan, dan penetapan mutu pendidikan terhadap berbagai komponen pendidikan pada setiap jalur, jenjang, dan jenis pendidikan sebagai bentuk pertanggung jawaban penyelanggaraan pendidikan. ${ }^{29}$ Jadi penilaian digunakan untuk mengukur suatu aktivitas kegiatan dengan mengukur atau mengevaluasi dari hasil yang dicapai dengan hasil sebelumnya.

\section{Peningkatan Kepercayaan Masyarakat}

Dalam Undang- Undang RI No.20 Tahun 2003 tentang sistem pendidikan nasional bab1 pasal 1 ayat 27 menyatakan bahwa masyarakat adalah kelompok warga Negara Indonesia non pemerintah yang mempunyai perhatian dan peranan dalam bidang pendidikan. Sedangkan dalam bab XV pasal 54 ayat 1 menyatakan bahwa peran serta masyarakat dalam pendidikan meliputi perseorangan, kelompok, keluarga, organisasi

${ }^{27}$ Mujahid, Dkk. (2003). Manajemen Madrasah Mandiri, Jakarta: Puslitbang Pendidikan agama Dan keagamaan, p.117

${ }^{28}$ Hikmat. (2009). Manajemen Pendidikan, Bandung: Pustaka Setia, p. 125

${ }^{29}$ Sekretariat Negara R.I.,(2003), Undang-Undang Republik Indonesia Nomor 20 Tahun 2003 Tentang Sistem Pendidikan Nasional, Jakarta: Armas Duta Jaya. 


\section{Abd Wahib}

profesi, pengusaha, dan orgnisasi kemasyarakatan dalam penyelenggaraan dan pengendalian mutu pelayanan pendidikan. ${ }^{30}$

Tidak jarang kita mendengar kata kepercayaan, dijelaskan dalam kamus bahasa Indonesia bahwa kepercayaan adalah anggapan atau keyakinan bahwa sesuatu yang dipercayai itu benar dan nyata. Sedangkan masyarakat adalah sejumlah manusia yang seluas-luasnya dan terikat oleh suatu kebudayaan yang mereka anggap sama. ${ }^{31}$ Kepercayaan masyarakat adalah sebuah keyakinan yang bembentuk proses terjalinya interaksi sosial yang memiliki kesamaan pandangan dan tindakan serta tujuan yang sama. $^{32}$

Jadi kepercayaan masyarakat adalah satu kesatuan manusia yang hidup dan tinggal di wilayah dan kawasan tertentu yang berkeyakinan dan saling percaya untuk memenuhi kebutuhan hidupnya sebagai mahluk individu dan mahluk sosial.

\section{Upaya Dalam Mencapai Kepercayaan Masyarakat}

a. Akomodasi

Akomodasi adalah suatu proses dimana orang perorang atau kelompok manusia yang mula-mula saling bertentangan kemudian saling menyesuaikan diri untuk mengatasi kekurangan-kekurngan. ${ }^{33}$ Sebagai warga masyarakat yang baik, kita dituntut tidak hanya tunduk pada kaidah hukum, tetapi juga kaidah moral, sosial dan budaya. Kaidah-kaidah ini seringkali tidak tertulis secara khusus dan berakar pada ajaran agama atau kebiasaan yang berlaku dalam masyarakat secara turuntemurun. ${ }^{34}$

\footnotetext{
${ }^{30}$ Sekretariat Negara R.I.,(2003), Undang-Undang Republik Indonesia Nomor 20 Tahun 2003

${ }^{31}$ Alya, Qonita. (2008). Kamus Bahasa Indinesia, Bandung: PT. Indah Jaya, p.539

${ }^{32}$ Setiawan, Iwan, Dkk. (2008) Wawasan Sosial, Jakarta: Departemen Pendidikan Nasional, p.66

33 Sudarmi, Sri. (2008). Galeri pengetahuan Sosial Terpadu, Jakarta: Departemen Pendidikan Nasional, p.239

${ }^{34}$ Miarso, Yusufhadi. (2005). Menyemai Benih Teknologi Pendidikan, Jakarta: prenada media,p.710
} 
Yang perlu diperhatikan dalam program hubungan masyarakat di lembaga pendidikan secara mendasar adalah pelibatan peran orang tua dan masyarakat dalam mengelola lingkungan sekolah. ${ }^{35}$

Dalam Undang- Undang RI No.20 Tahun 2003 tentang sistem pendidikan nasional bab1 ayat 16 menyatakan bahwa pendidikan berbasis masyarakat adalah penyelenggaraan pendidikan berdasarkan khasanah agama, social, budaya, aspirasi, dan potensi masyarakat sebagai perwujudan pendidikan dari, oleh, dan untuk masyarakat.

Berdasarkan penjelasan di atas maka penyelenggaraan hubungan Madrasah dengan masyarakat bertujuan untuk:

1. Memelihara kelangsungan hidup sekolah.

2. Meningkatkan mutu pendidikan di Madrasah yang bersangkutan.

3. Memperlancar proses belajar mengajar.

4. Memperoleh dukungan dan bantuan dari masyarakat yang diperlukan dalam pengembangan dan pelaksanaan program Madrasah.

b. Kerja sama

Kerja sama (cooperation) merupakan proses sosial yang paling utama. Kerjasama adalah suatu usaha bersama antar pribadi atau antar kelompok manusia untuk mencapai suatu tujuan secara bersama-sama. Secara sederhana hubungan atau communication dapat diartikan sebagai proses penyampaian berita dari seseorang kapada orang lain. Komunikasi dalam administrasi Sekolah adalah suatu proses penyampain sesuatu (berita/ide kepada orang lain), hal ini bisa secara intern yaitu didalam organisasi sekolah itu sendiri. Juga bisa ekstern, artinya antara sekolah dengan pihah lain (ke luar) masyarakat lembaga/intansiyang lain. ${ }^{36}$

Allah berfirman dalam Al-Qur'an surat Al-Maidah ayat 2 yang berbunyi:

35 Mulyono. (2008). Manajemen Administrasi \& Organisasi Pendidikan, Jogjakarta: Ar-Ruzz Media,p.204

${ }^{36}$ Sudarmi, Sri. (2008). Galeri pengetahuan Sosial Terpadu, Jakarta: Departemen Pendidikan Nasional, p.69 
Abd Wahib

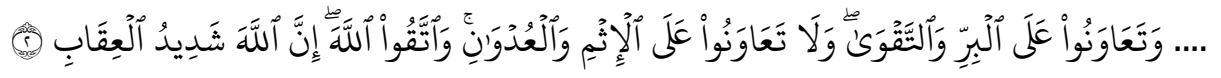

Artinya:

...Dan tolong menolonglah kamu dalam mengerjakan kebaikan dan takwa, dan jangan tolong menolong dalam berbuat dosa dan pelanggaran, dan bertakwalah kamu kepada Allah, sesungguhnya Allah amat berat siksa-Nya (Qs. Al-maidah, 5:2) (Depag RI, 1990:156).

Jadi kerja sama merupakan bentuk kegiatan yang dilakukan dengan cara menerima unsur-unsur baru dalam kepemimpinan suatu organisasi (lembaga pendidikan) sebagai salah satu cara untuk menghindari terjadinya kegoncangan stabilitas organisasi yang bersangkutan.

c. Asimilasi

Asimilasi adalah proses sosial yang timbul apabila kelompok masyarakat dengan latar belakang kehidupan yang berbeda saling bergaul secara interaktif dalam jangka waktu yang lama. Akibat dari asimilasi adalah kebudayaan asli akan berubah sifat dan wujudnya membentuk kebudayaan yang baru yang merupakan penyatuan kebudayaan dan masyarakat dengan tidak membedakan antara masyarakat yang lama dengan masyarakat yamh baru. ${ }^{37}$

Dalam Undang- Undang RI No.20 Tahun 2003 tentang sistem pendidikan nasional bab IV pasal 8-9 menyatakan bahwa masyarakat berhak berperan serta dalam perencanaan, pelaksanaan, pengawasan, dan evaluasi program pendidikan. Serta masyarakat berkewajiban memberikan dukungan sumber daya dalam penyelenggaraan pendidikan.

Sedangkan hakikat hubungan masyarakat dalam manajemen pendidikan Islam dapat kita artikan sebagai suatu proses hubungan timbal balik antara lembaga pendidikan Islam dengan masyarakat yang dilandasi dengan iktikad saling mengenal (ta'aruf), saling memehami (tafabum), saling mengasihi (tarahum), saling menolong (ta'awun), dan saling menanggung (takaful) dalam rangka mencapai

${ }^{37}$ Ibid, 244 
tujuan pendidikan yang telah direncanakan sebelumnya yang didasarkan pada nilai-nilai dalam ajaran Islam. ${ }^{38}$

Sebagaimana firman Allah SWT. Dalam Al-Qur'an surat Al-Imran ayat 112 yaitu:

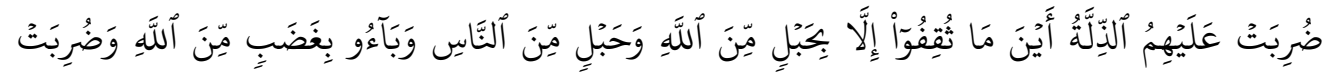

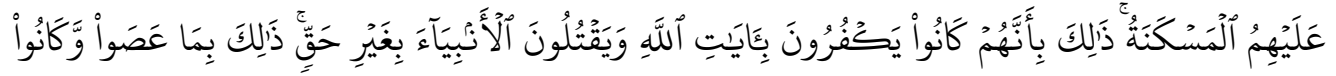
يَ يْنَتُونَ

Artinya:

Mereka diliputi kehinaan di mana saja mereka berada, kecuali jika mereka berpegang kepada tali (agama) Allah dan tali (perjanjian) dengan manusia, dan mereka kembali mendapat kemurkaan dari Allah dan mereka diliputi kerendahan. yang demikian itu karena mereka kafir kepada ayat-ayat Allah dan membunuh Para Nabi tanpa alasan yang benar. yang demikian itu disebabkan mereka durhaka dan melampaui batas (Qs. Al-Imran:112).

Berdasarkan pendapat diatas dapat disimpulkan bahwa asimilasi merupakan suatu proses terjalinnya hubungan sosial yang mengarah pada bentuk jalinan sosial yang erat, saling membutuhkan dan terbentuk hubungan kerja sama yang saling menguntungkan.

Jadi peranan manajemen lembaga dalam meningkatkan kepercayaan masyarakat adalah kegiatan pengelolaan lembaga pendidikan Islam yang dilakukan dengan memberdayakan sumber daya yang ada dalam rangka mencapai tujuan yang sudah ditentukan guna memperoleh dukungan dan kepercayaan masyarakat.

\section{KESIMPULAN}

Peranan manajemen lembaga dalam meningkatkan kepercayaan masyarakat yang terdiri dari fungsi dan aplikasi manajemen maupun peningkatan kepercayaan masyarakat. Mengaplikasikan fungsi manajemen dalam meningkatkan kepercayaan masyarakat. kepala Madrasah, guru, dan karyawan dapat menjalankan tugasnya dengan baik dalam meningkatkan kepercayaan masyarakat yang meliputi: akomodasi, kerja sama, dan asimilasi. Aplikasi manajemen lembaga dalam meningkatkan kepercayaan. Untuk itu diharapkan kepada kepala Madrasah atau sekolah untuk tidak segan-segan memotivasi

${ }^{38}$ Mulyono. (2008). Manajemen Administrasi \& Organisasi Pendidikan, Jogjakarta: Ar-Ruzz Media,p.209 
Abd Wahib

dan memberikan arahan dalam menjalankan tugas kepada bawahan dalam mencapai tujuan baik kualitas mupun kuantitas dapat dicapai sesuai dengan harapan bersama. Kepada para guru dan karyawan agar selalu bersikap kreatif dan inovatif sehingga perkembangan dan kemajuan lembaga sejalan dengan kebutuhan masyarakat dan

perkembangan zaman. Tentunya harapan kepada peserta didik untuk selalu rajin belajar dan menjaga nama baik lembaga, karena tantangan dimasa yang akan datang lebih berat, maka dari itu sebagai generasi penerus pejuang bangsa haruslah mempersiapkan diri untuk menghadapi kehidupan dimasa yang akan datang.

\section{DAFTAR PUSTAKA}

Qomar, Mujammil. (2007). Manajemen Pendidikan Islam, Malang: Erlangga.

Departemen Agama Republik Indonesia, (1990). Al-Qur'an dan Terjamahnya, Surabaya: Mahkota.

Nata, Abuddin. (2008). Manajemen Pendidikan Mengatasi kelemahan Pendidikan Islam Di Indonesia, Jakarta: Kencana Prenada Media Group.

Mujahid, Dkk. (2003). Manajemen Madrasab Mandiri, Jakarta: Puslitbang Pendidikan agama Dan keagamaan.

Mulyono. (2008). Manajemen Administrasi \& Organisasi Pendidikan, Jogjakarta: Ar-Ruzz Media.

Suryosubrato. (2004). Manajemen Pendidikan Di Sekolah, Jakarta: Reneka Cipta.

Sekretariat Negara R.I.,(2003), Undang-Undang Republik. Indonesia Nomor 20 Tabun 2003 Tentang Sistem Pendidikan Nasional, Jakarta: Armas Duta Jaya.

Fattah, Nanang. (2003). Landasan Manajemen, Bandung: PT. Remaja Rosdakarya.

Daryanto. (1998). Administrasi pendidikan, Jakarta, Reneka Cipta.

Hikmat. (2009). Manajemen Pendidikan, Bandung: Pustaka Setia.

Mulyono. (2008). Manajemen Administrasi \& Organisasi Pendidikan, Jogjakarta: Ar-Ruzz Media.

Purwanto, Ngalim. (2009). Administrasi Dan Supervisi Pendidikan, Bandung: PT. Remaja Rosdakarya.

Alya, Qonita. (2008). Kamus Bahasa Indinesia, Bandung: PT. Indah Jaya,

Setiawan, Iwan, Dkk. (2008) W awasan Sosial, Jakarta: Departemen Pendidikan Nasional.

Sudarmi, Sri. (2008). Galeri pengetahuan Sosial Terpadu, Jakarta: Departemen Pendidikan Nasional.

Miarso, Yusufhadi. (2005). Menyemai Benih Teknologi Pendidikan, Jakarta: prenada media. 